\title{
Microhardness of Resin-Based Materials Polymerized with LED and Halogen Curing Units
}

\author{
Daniela Francisca Gigo CEFALY ${ }^{1}$ \\ Giovano Augusto de Oliveira FERRAREZI² \\ Celiane Mary Carneiro TAPETY ${ }^{3}$ \\ José Roberto Pereira LAURIS ${ }^{4}$ \\ Maria Fidela de Lima NAVARRO ${ }^{3}$ \\ ${ }^{1}$ Department of Operative Dentistry, University North of Paraná, Londrina, PR, Brazil \\ ${ }^{2}$ Department of Prosthodontics, Hospital for Rehabilitation of Craniofacial Anomalies, \\ University of São Paulo, Bauru, SP, Brazil \\ ${ }^{3}$ Department of Operative Dentistry, Endodontics and Dental Materials and ${ }^{4}$ Department of Pediatric Dentistry, \\ Orthodontic and Collective Health, Faculty of Dentistry of Bauru, University of São Paulo, Bauru, SP, Brazil
}

\begin{abstract}
The purpose of this study was to evaluate the microhardness of resin-based materials polymerized with a LED (light-emitting diode) light-curing unit (LCU) and a halogen LCU. Twenty cylindrical specimens (3.0 $\mathrm{mm}$ in diameter and $2.0 \mathrm{~mm}$ high) were prepared for each tested material (Z100, Definite and Dyract). Specimens were light-cured with two LCUs (Ultraled and Curing Light 2500$)$ for either 40 or $60 \mathrm{~s}$ on their top surfaces. Hardness was measured on top and bottom surfaces of each specimen. Statistical analysis was done by ANOVA and Tukey's test $(\mathrm{p}<0.05)$. There was no significant difference in hardness between LED LCU and halogen LCU for Z100 and Dyract on top surface. Conversely, lower hardness was recorded when Definite was light-cured with the LED LCU than with the halogen lamp. On bottom surface, hardness was significantly lower for all materials light-cured with LED LCU. Z100 was harder than Dyract and Definite regardless of the light curing unit. There was no significant difference in hardness between the exposure times on top surface. Higher hardness was obtained when the materials were light-cured for $60 \mathrm{~s}$ on bottom surface. The tested LED was not able to produce the same microhardness of resin-based materials as the halogen LCU.
\end{abstract}

Key Words: microhardness, composite, light emitting diodes (LED).

\section{INTRODUCTION}

Halogen lamps are the most frequently used sources for polymerization of resin-based dental materials. Their benefits include low cost technology while their drawbacks involve the production of high temperatures and decline of irradiance over time due to bulb and filter ageing $(1,2)$.

Different technologies for light curing composite resins like plasma arc lamps, laser and LED (light emitting diode) have been developed and investigated (3-5).

LED technology seems to be the most promising. The visible light of a LED is produced by quantummechanical effects differently from halogen lamps that need heating of metal filaments. Basically, LED is a combination of two different semiconductors. When a voltage is applied, the electrons from one semiconductor and the lack of electrons from the other are connected, resulting in light emission. Its benefits include microelectronics (that allow manufacturing of smaller devices) and a narrow emission spectrum that falls closely within the absorption range of camphoroquinone, which is, in turn, the most commonly used initiator of cure of resin monomers (6). As a consequence, the light emitted by LED lamps is much more efficient. However, some studies have reported worse properties of resins cured with LED light-curing units (LCUs) compared to those cured with halogen lamps $(7,8)$.

Previous studies on the dental application of LEDs involve polymerization of composite resins (5,710). However, different resin-based materials, such as 
compomers, also need photoactivation and therefore studies using LEDs to cure such a class of materials are necessary. In the same way, the ability of LEDs in curing resins that have different initiators should be tested because previously investigated resins had camphoroquinone as photoinitiator (5,7-10).

Microhardness testing has been widely used as a viable method to assess the relative degree of cure of resins and therefore the efficiency of the light source $(5,7)$.

The purpose of this study was to evaluate the microhardness on top and bottom surfaces of a composite resin that has camphorquinone as initiator, a composite resin that has a combination of initiators and a compomer polymerized with either a LED or a halogen LCU, using two exposure times.

\section{MATERIAL AND METHODS}

Twenty cylindrical specimens $(3.0 \mathrm{~mm}$ in diameter and $2.0 \mathrm{~mm}$ high) were prepared for each tested material: Z100 (composite resin - 3M Dental Products, St. Paul, MN USA); Definite (composite resin - Degussa, Hanau, Germany); Dyract (compomer - Dentsply De Trey, Konstanz, Germany). $A_{2}$ shade was used for all materials. Each group of specimens was divided into 4 sub-groups $(\mathrm{n}=5)$ that were polymerized using two light-curing units: a LED with power density of 130 $\mathrm{mW} / \mathrm{cm}^{2}$ (Ultraled; Dabi Atlante, Ribeirão Preto, SP, Brazil) and a halogen lamp with power density of 760 $\mathrm{mW} / \mathrm{cm}^{2}$ (Curing Light 2500; 3M Dental Products). The specimens were light-cured for either 40 or $60 \mathrm{~s}$ on their top surface.

For specimen preparation, a stainless steel mold was placed on a clear polyester strip. The material was placed into the mold and covered with another clear polyester strip and a thin, clear cover glass to obtain a flat polymerized surface. Finger pressure was applied onto the slide to extrude excess material, the slide was removed and the material was polymerized with the LCUs and exposure times (40 s and $60 \mathrm{~s}$ ) under study. LCUs power densities were measured using a calibrated power meter (Field Master; Coherent, Santa Clara, CA, USA). The top surface was identified with an indelible marker. All specimens were prepared in a temperaturecontrolled room at $23 \pm 1^{\circ} \mathrm{C}$.

Specimens were stored in distilled water in a lightproof container for $24 \mathrm{~h}$ and hardness was measured using a microhardness tester (Carl Zeiss, Jena, GmbH Germany) with a marker for Vickers units. Hardness indentations were made on top and bottom surfaces of each specimen. Three readings with a $50 \mathrm{~g}$ load for 15 $\mathrm{s}$ were taken on each surface and the average was converted into a Vickers Hardness Number (VHN).

Data were analyzed statistically using a fourway (light curing unit, material, exposure time and surface) analysis of variance (ANOVA). There was statistically significant interaction between the surface and the other three variables under study. Therefore, the surfaces were analyzed separately. For each surface (top and bottom), the influence of the variables material, curing unit and exposure time on microhardness was tested using a three-way analysis of variance and Tukey's test for multiple comparisons $(\mathrm{p}<0.05)$. Comparisons between the surfaces for each combination material/curing unit/exposure time were made by oneway ANOVA $(\mathrm{p}<0.05)$.

\section{RESULTS}

Means (and standard deviation) of Vickers hardness are given on Table 1.

Three-way ANOVA results are described below for each variable separately.

Light-curing unit - Top: there was no significant difference in hardness between LED and halogen lamp for Z100 and Dyract. However, lower hardness was obtained when Definite resin composite was light-cured with the LED LCU. Bottom: hardness was significantly lower for all the materials light-cured with LED.

Material - Top and bottom: Z100 was harder than Dyract and Definite regardless of the light-curing unit. Definite was harder than Dyract when the materials were light-cured with halogen LCU. There was no significant difference between Definte and Dyract hardness for LED LCU.

Exposure time - Top: there was no significant difference in hardness between the exposure times (40 and $60 \mathrm{~s}$ ). Bottom: higher hardness was obtained when the materials were light-cured for $60 \mathrm{~s}$.

The one-way analysis of variance showed no statistically significant difference between the hardness measurements on top and bottom surfaces of Z100 composite resin, regardless of the LCU and exposure times $(p>0.05)$. However, the hardness on bottom surface of Definite specimens was significantly lower 
than that on top surface when the material was cured with both LED and halogen lamp. Similarly, the bottom surface hardness of Dyract cured with LED unit was significantly lower than that of the top surface, but no difference was found when Dyract was cured with the halogen lamp.

Table 1: Means (and SD) of VHN on top and bottom surfaces of the studied materials for each tested curing unit and exposure time (40 $\mathrm{s}$ and $60 \mathrm{~s})$.

\begin{tabular}{lccccr}
\hline Material/LCU & \multicolumn{2}{c}{ Top Surface } & & \multicolumn{2}{c}{ Bottom Surface } \\
\cline { 2 - 3 } \cline { 5 - 6 } & $40 \mathrm{~s}$ & $60 \mathrm{~s}$ & & $40 \mathrm{~s}$ & $60 \mathrm{~s}$ \\
\hline $\mathrm{Z100} / \mathrm{LED}$ & $110.56 \pm 8.68 \mathrm{a}$ & $108.21 \pm 2.95 \mathrm{a}$ & & $101.07 \pm 1.53 \mathrm{a}$ & $108.24 \pm 9.70 \mathrm{f}$ \\
$\mathrm{Z100} /$ Halogen & $113.60 \pm 8.56 \mathrm{a}$ & $108.61 \pm 11.50 \mathrm{a}$ & & $113.03 \pm 10.53 \mathrm{~b}$ & $113.44 \pm 8.93 \mathrm{~g}$ \\
Definite / LED & $42.43 \pm 3.13 \mathrm{~b}$ & $44.53 \pm 2.90 \mathrm{~b}$ & & $27.67 \pm 2.70 \mathrm{c}$ & $34.09 \pm 2.59 \mathrm{~h}$ \\
Definite / Halogen & $80.27 \pm 11.93 \mathrm{c}$ & $72.25 \pm 5.79 \mathrm{c}$ & & $53.86 \pm 8.01 \mathrm{~d}$ & $65.09 \pm 5.42 \mathrm{i}$ \\
Dyract / LED & $40.50 \pm 3.84 \mathrm{~b}$ & $41.65 \pm 4.88 \mathrm{~b}$ & & $25.23 \pm 3.95 \mathrm{c}$ & $32.33 \pm 1.69 \mathrm{~h}$ \\
Dyract / Halogen & $44.69 \pm 3.36 \mathrm{~b}$ & $44.20 \pm 4.64 \mathrm{~b}$ & & $40.99 \pm 5.26 \mathrm{e}$ & $45.15 \pm 4.98 \mathrm{j}$ \\
\hline
\end{tabular}

Different letters indicate statistically significant difference for comparisons in the same column and in the same line. LCU: Light-curing unit. LED: Light-emitting diode. VHN: Vickers Hardness Number.

\section{DISCUSSION}

Since the introduction of the LED lamps, there has been an increased interest in comparing their ability to cure resin composites to that of regular halogen lamps. Some studies have shown that minimum requirements of depth of cure according to ISO 4049 and similar mechanical properties can be achieved by LED lamps (8). At the same low power density (i.e, 100 $\mathrm{mW} / \mathrm{cm}^{2}$ ), LED lamps can result in even deeper curing and higher degree of conversion than halogen lamps (9). Conversely, Kurachi et al. (5) reported that the LED investigated in their study $\left(79 \mathrm{~mW} / \mathrm{cm}^{2}\right)$ required approximately $100 \mathrm{~s}$ to produce the same Vickers hardness that the halogen lamp $\left(475 \mathrm{~mW} / \mathrm{cm}^{2}\right)$ produced in $40 \mathrm{~s}$ at a depth of $1.8 \mathrm{~mm}$. Dunn and Bush (7) demonstrated that halogen-based light curing units ( 900 and $1030 \mathrm{~mW} / \mathrm{cm}^{2}$ ) produced significantly harder top and bottom composite surfaces than the two commercially available LED units tested $(150 \mathrm{~mW} /$ $\left.\mathrm{cm}^{2}\right)$. The results of the present investigation are partially consistent with those of these studies $(7,9)$. On top surfaces, hardness of Z100 (composite resin) and Dyract (compomer) specimens polymerized with the LED LCU was not different from that of the specimens cured with the halogen LCU. However, hardness on the bottom surfaces ( $2 \mathrm{~mm}$ deep) of all materials cured with the halogen unit was significantly higher.

Definite was the only material that presented a significantly lower hardness on top surface when cured with LED unit than with the halogen lamp. This may be explained by differences in LED and halogen lamp ability to excite the photoinitiators present in the materials. Halogen lamps used in conventional curing units have a 360-500 nm spectrum range. Most resin-based materials have camphorquinone as the initiator of curing, which is sensitive to light at the blue region of the visible spectrum. According to Nomoto (11), the most efficient wavelength is $470 \mathrm{~nm}$, and the blue LED light has a wavelength of around $470 \mathrm{~nm}$ with a bandwidth of about $20 \mathrm{~nm}$. Therefore, it produces highly efficient curing without overheating.

Although camphorquinone is the most commonly used photoinitiator, it has some limitations, and hence some materials contain other initiators of cure that are not excited within the wavelength range covered by LED lamps. The BAPO (bis-acyl phosphine oxide) and the PPD (1-phenyl-1,2-propanodione), for example, are initiators with absorption peaks at $380 \mathrm{~nm}$ and $410 \mathrm{~nm}$, respectively, which are not efficiently polymerized by LED LCUs. Definite contains a mixture of photoinitiators (personal communication), with less camphorquinone content, which could compromise material polymerization when the LED lamp was used. 
The lower hardness on the bottom surface of materials cured with the LED LCU may possibly be explained by the irradiance or power density of the units. The LED device used in this study is composed by 7 blue light-emitting diodes and provides a $130 \mathrm{~mW} / \mathrm{cm}^{2}$ power density, while the halogen-based LCU has a $760 \mathrm{~mW} /$ $\mathrm{cm}^{2}$ power density. The increase in exposure time from 40 to $60 \mathrm{~s}$ with the LED unit was not sufficient to produce the same hardness obtained with the halogen lamp on the bottom surface. Perhaps, power density of LEDs should be increased to obtain resin-based materials with hardness comparable to that of materials polymerized with halogen LCUs.

Another interesting issue observed in this study was the lower hardness on the bottom than on the top surface of Definite resin cured with halogen LCU in both exposure times. Hardness on top surface was approximately $33 \%$ and $10 \%$ (for $40 \mathrm{~s}$ and $60 \mathrm{~s}$, respectively) higher than on the bottom surface. There was no statistically significant difference between hardness on top and bottom surfaces for the other materials cured with halogen light. While the bottom surface of Z100 resin was approximately $10 \%$ harder when cured with halogen lamp than when cured with LED, such differences were more pronounced for Definite and Dyract (approximately 30\%). The possible explanation is that polymerization of a resin is affected by characteristics inherent to the specific material being cured. The composite filler type and its shade influence material polymerization $(7,12,13)$. Definite composite resin is based on "ormocer" (organically modified ceramic) technology. It has an inorganic-organic copolymer matrix and its filler content (barium glass/ silica; $1-15 \mu \mathrm{m}$ on average) is $77 \%$ by weight. Z100, which showed the highest hardness, is a hybrid composite with filler content (zirconia/silica; $0.6 \mu \mathrm{m}$ on average) of $84 \%$ by weight. Dyract filler content (glass: $0.8 \mu \mathrm{m}$ average) is about $73 \%$ by weight. It is a compomer, a term derived by combining parts of the two words COMPosite and ionoMER, and is a material intended to combine resin composite and glass ionomer technology. Even though the same shade (A2) was used for all materials, their filler types are different. Therefore, the light attenuation throughout materials and the polymerization efficiency on bottom surfaces were different for each material (14).

In addition to mechanical tests, different analyses of resin-based materials polymerized by LED LCU should be conducted. The conversion rate of methacrylate carbon-carbon double bonds to an extended network of double bonds of resin polymerized by LEDs is an important characteristic. Discoloration and increased water sorption will probably occur as a result of a low conversion rate. Moreover, organic molecules eluted from the resin may have a negative biological effect, which is inversely related to the degree of cure (15). Other studies of physical and mechanical properties of materials cured with LEDs are needed, as well as additional investigations with different materials such as resin-modified glass-ionomers cements.

In conclusion, at a depth of $2 \mathrm{~mm}$, the surface of resin-based materials polymerized with a LED lightcuring unit was not as hard as that obtained when the materials cured with a halogen lamp Furthermore, the tested LED did not have the same performance as that of the halogen lamp in polymerizing a composite resin that has a combination of photoinitiators in its formulation instead of camphorquinone only.

\section{RESUMO}

O objetivo deste estudo foi avaliar a microdureza de materiais resinosos polimerizados com unidades de fotoativação LED (diodos emissores de luz) e halógena. Vinte espécimes cilíndricos (3,0 $\mathrm{mm}$ de diâmetro e 2,0 $\mathrm{mm}$ de altura) foram preparados para cada material testado (Z100, Definite e Dyract). Os espécimes foram fotoativados na face superior (topo), utilizando duas unidades de fotoativação (Ultraled and Curing Light 2500), com tempos de $40 \mathrm{~s} \mathrm{e} 60 \mathrm{~s}$. As medidas de dureza foram realizadas nas superfícies do topo e da base de cada espécime. A análise estatística foi realizada por ANOVA e teste de Tukey $(p<0,05)$. Não houve diferença significante na dureza na face superior entre as unidades LED e halógena para a Z100 e o Dyract. Por outro lado, a dureza foi menor quando a Definite foi polimerizada com o LED do que com a unidade halógena. Na base, a dureza de todos os materiais foi menor com o LED do que com a unidade halógena. A Z100 apresentou maior dureza que o Dyract e que a Definite independentemente da unidade de fotoativação. Não houve diferença significante na dureza entre os dois tempos de fotoativação para a face superior. $\mathrm{Na}$ base, a dureza foi maior quando os materiais foram polimerizados por $60 \mathrm{~s}$. O LED não foi capaz de produzir a mesma dureza que a unidade halógena nos materiais resinosos testados.

\section{REFERENCES}

1. Martin FE. A survey of the efficiency of visible light curing units. J Dent 1998;26:239-243.

2. Miyazaki M, Hattori T, Ichiishi Y, Kondo M, Onose $H$, Moore BK. Evaluation of curing units used in private dental offices. Oper Dent 1998;23:50-54. 
3. Rueggeberg FA, Ergle JW, Mettenburg DJ. Polymerization depths of contemporary light-curing units using microhardness. J Esthet Dent 2000;12:340-349.

4. Vargas MA, Cobb DS, Schmit JL. Polymerization of composite resins: argon laser vs conventional light. Oper Dent 1998;23:87-93.

5. Kurachi C, Tuboy AM, Magalhães DV, Bagnato VS. Hardness evaluation of a dental composite polymerized with experimental LED-based devices. Dent Mater 2001;17:309315.

6. Mills RW, Jandt KD, Ashworth SH. Dental composite depth of cure with halogen and blue light emitting diode technology. Br Dent J 1999;186:388-391.

7. Dunn WJ, Bush AC. A comparison of polymerization by light-emitting diode and halogen-based light-curing units. $\mathrm{J}$ Am Dent Assoc 2002;133:335-341.

8. Jandt KD, Mills RW, Blackwell GB, Ashworth SH. Depth of cure and compressive strength of dental composites cured with blue light emitting diodes (LEDs). Dent Mater 2000;16:41-47.

9. Stahl F, Ashworth SH, Jandt KD, Mills RW. Light-emitting diode (LED) polymerization of dental composites: flexural properties and polymerization potential. Biomaterials 2000;21:1379-1385

10. Knezevic A, Tarle Z, Meniga A, Sutalo J, Pichler G, Ristic M. Degree of conversion and temperature rise during polymerization of composite resin samples with blue diodes. J Oral Rehabil 2001;28:586-591.

11. Nomoto R. Effect of light wavelength on polymerization of light-cured resins. Dent Mater J 1997;16:60-73.

12. Forsten L. Curing depth of visible light-activated composites. Acta Odontol Scand 1984;42:23-28.

13. Leonard DL, Charlton DG, Roberts HR, Hilton TJ, Zionic A Determination of the minimum irradiance required for adequate polymerization of a hybrid and a microfill composite. Oper Dent 2001;26:176-180.

14. Rueggeberg FA, Caughman WF, Curtis JW, Davis, HC. Factors affecting cure at depths within light-activated resin composites. J Dent 1993;6:91-95.

15. Geurtsen W. Biological interactions of non-metallic restorative materials with oral tissues. Trans Acad Dent Mater 1999; 13:75-93

Accepted March 3, 2005 